\title{
An Exposition on Principals' Influence in Real Estate Negotiation
}

\author{
Iroham, C. O. (Corresponding author) \\ Department of Estate Management \\ College of Science and Technology \\ Covenant University, Ota, Ogun State, Nigeria \\ Tel: 234-803-679-5013 E-mail: emeka_iroham@yahoo.co.uk
}

Oluwunmi, A. O. and Oluwatobi. A. O.

Department of Estate Management

College of Science and Technology

Covenant University, Ota, Ogun State, Nigeria

Received: February 17, 2011 Accepted: February 31, 2011 doi:10.5539/ijms.v3n2p169

\begin{abstract}
The conflicting interest between principals' and the intermediary role played by Estate Surveyors and Valuers during real estate negotiation could prone the latter to influence from these principals' as evident in valuation. The research which entailed a survey of 159 Estate Surveyors and Valuers in Lagos metropolis was analyzed with the use of descriptive statistics and the Relative Important Index. It was discovered that potential tenants are most apt in influencing real estate negotiation which is usually carried out with the use of reward powers and information power where pecuniary gains are offered to Estate Surveyors and Valuers in order to accomplish their whims while access to information by these principals are also used against the Estate Surveyor and Valuer working in an unfamiliar terrain respectively.

The researchers therefore opines that a wakeup call by both the Nigerian Institution of Estate Surveyors and Valuers and the Estate Surveyors and Valuers Registration Board of Nigeria in curbing the prevalence of this influence will help preserve the integrity of the Estate Surveying and valuation profession.
\end{abstract}

Keywords: Principal, Estate surveyor and valuer, Influence, Negotiation, Real estate

\section{Introduction}

Outcomes in the property market are set on an individual transaction basis by negotiators whose motives, talent, and aspirations are usually conflicting. This usually ends up in an agreement that is preconceived at the same time as a "win-win situation" by parties involved ((Muhlebach, 2005; Morris, 1990). According to Neale and Bazerman (1992b) the greatest performance and potential for improvement in negotiation lies on access to information. There is an envisaged inexorability in negotiation in the property market as every stake holder works on available information in a bid to at least satisfying ones' position. An aftermath of a study by Institute for Corporate Real Estate (1992) identified negotiation as the key skill for success in corporate real estate, the study revealed that industries in a bid for improved results are dedicating more resources to the negotiation effort; also over the years there has been much importance ascribed to the real estate negotiation process (Rondeau, 1993). Hence, research has revealed advocates of improved models in order to enhance performances in the negotiating process particularly by authors in the behaviourial sciences, while (Neale and Bazerman, 1992a) argue that effective negotiation models must embody descriptive elements; Thompson (1990) suggests that psychological theories of negotiation should include motivational and cognitive dimensions.

Notwithstanding the call on the importance attached to negotiation in real estate dealings, the subject has only been stressed by a small number of research activities. Black and Diaz (1996) in a series of experiments on property negotiation focusing on anchoring effects, in which students and real estate professionals were asked to simulate a bargaining situation, reveals an inappropriate weighting of asking prices, even if those were inconsistent with available market data. In the same way Aycock (1999), tested the relative strengths of asking prices versus initial purchase prices as anchors in negotiated settlements. However, the author focused on 
property professionals and their buyer knowledge; while issues on negotiation were left aside.

Instances of a party having multiple negotiating experiences with the opposite party came up in the research carried out by Asami and Teraki (1991). The authors attempted to find an optimal order of negotiation for a real estate developer facing sequential negotiation with several landowners by analyzing models of land procurement by a developer. The researcher suggests that it may be optimal for the developer to procure land unit which is never used in the development, so as to strengthen his bargaining position. Moreover in the case of differential size in landowners' units where all units are required, the developer will likely choose to negotiate with the owner with the largest land unit so as to maximize his payoff.

The introduction of a third party usually referred to as agents in real estate negotiation took various detection in real estate research. Bazerman et al. (1992) discovered that while the use of a third-party mediator produced little impact on settlement price, the use of a real estate agent increased the settlement price as well as the probability of deadlock. Valley et al. (1992) on the impact of information shared with third-party real estate agents discovered that settlement prices were higher when buyer reservation prices were shared with agents and lowest when agents knew only seller reservation prices. In lease negotiation, Pfrang and Wittig (2008) showed that brokers' influence on the behaviour of the negotiating partners can contribute to the efficiency of negotiation processes and the perceived contract utility. There was also the identification of mutual concessions and the creation of incentives and additional negotiation subjects as possibilities in improving the attractiveness of a lease contract and also in reaching more beneficial contract provisions. These the authors achieved by modeling a game-theoretical framework that covers the basic mechanisms of lease contract negotiations while making allowance for relevant behavioural aspects.

Other researches in lease negotiation have been approached from various perspectives. Hutchison et al. (2010) considered the negotiating strengths of landlords and tenants in lease negotiation. The study being comparative in nature between the well established deposit system in Seoul, the South Korean market, geared towards the application of same in the UK market, was aimed at calculating the level of deposit necessary to mitigate any inherent income risk particularly during the down phase of the property cycle when supply of space exceeds demand and business conditions are uncertain. It was discovered that tenants were unwilling to pay deposits and landlords were more inclined to offer incentives in a bid to get the property let, even though the down phase is exactly the time when a deposit system is needed most. The researchers thereby suggested that landlords should be looking through the cycle and insisting that deposits are paid at the height of the market when their bargaining strength is stronger. The deposit is required to be sufficient, at least 15 months' rent, so as to cover the probability of income loss in the down phase of the cycle. McAllister and Tarbert (1999) analysed the rental negotiation process prior to lease expiry. The authors tested the findings from earlier research that tenants may use the threat of lease termination at rental negotiations in order to obtain concessions in the rent or other incentives. The authors noted that the bargaining process will often cause deviation from what they term as an equilibrium solution. In their analysis the concession level of the landlord was discovered to be a function of four variables comprising the expected landlord's cost of void, probability of tenant relocation, landlord's risk preference and the effects of the bargaining process. Also within rental negotiations, the differences between rent reviews/lease renewals and open market lettings were examined by Crosby and Murdoch (2000). The authors argued that in both rent reviews and lease renewals the rental negotiations were usually on a one-to-one basis which contrasts with open market lettings where a full marketing process normally occurs. At rent review/lease renewal, if there was an inability to agree, third parties may determine the rent at review or renewal. This contrasted with the case of an open market letting where the absence of agreement may cause the proposed deal to collapse.

The estate agent who has prominent role to play particularly as it regards bringing two separate parties together should have what it takes to build confidence in them. This would invariably amongst others reduce if not totally eliminate dual-loyalty conflict agents' face from principals (Kurtzberg et al., 2005). One way of eliminating such could be by training and education. Myerscough and Tyler (1991) advocated the need for negotiation education; the case for formal negotiation training, the provision of training for the surveyors, timing of the training provision, and the effectiveness of various teaching methods for training the surveyor was outlined. ElShenawy (2010) tested the main effect of negotiation training-level on acquiring negotiation skills. Six meta-analyses were conducted over 57 lab experiments from 36 studies. The six meta-analyses were divided into two groups each with a sub-study. The objective of study one was finding the effect of training level on negotiators' individual and joint performance while the objective of study two is contrasting the effects of three training levels on negotiators' performance. The study sustained the position as discoveries were made of an increase in negotiators' performance linked to higher training level. Hardin (1997) discovery on the function of training on 
the subject of real estate negotiation was from a banker's perspective, coming to the conclusion that a lender's perception of the attractiveness of a potential loan was a function of the lender's training and experience. Ashcroft (2004) recognizing the difficulty in assessing outcomes of commercial negotiation; such as the impact on the short- and long-term buyer/seller relationship and the negotiator's personal and organizational development buttressed the need for negotiators' to understand and develop commercial negotiation skills in the context of the buying/selling dynamics using the writer's experience as a Lead Negotiator. The author explored the commercial negotiation skills from three perspectives; the process, the respective parties' objectives and bargaining. The author however acknowledges that deriving such commercial negotiation skills though valuable could be demanding, and often a personally challenging task. Apart from the acquisition of cognate skills in real estate negotiation, planning has also been regarded as a veritable requirement in such operation (Nourse, 1990).

Estate agents without prejudice to what they are being called anywhere around the globe are involved in various negotiations from principals such as vendors, buyers, landlords, tenants, prospective landlord and prospective tenants, perhaps due to their role as the intermediary between/amongst these principals. It could be arguable then that this situation could expose the agent to various forms of influence by these principals so as to attain their whims as has been established in real estate valuation process (Amidu and Aluko, 2007; Baum et. al., 2000; Chinloy, Cho and Megbolugbe, 1997; Cho and Megbolugbe, 1996; Crosby et al., 2004; Iroham, 2007; Kinnard, Lenk and Worzala, 1997; Ogunba, 1997)

Chen and Yu (2009) attempted to analyze client influence on valuation both in Taiwan and Singapore. The choice of both countries was due to their similar level of economic development as well as professionalism amongst valuers practicing in the countries. However, although both are Chinese-dominated by population, the culture and language used are substantially different. The study used a survey questionnaire to sample valuers' response to client influence in both Taiwan and Singapore. The questionnaire was organized into five parts: social economic data, client influence situation, potential factors, influence method, and influence abilities. The survey findings were analyzed using SPSS and subjected to a number of standard procedures to check for missing values and multivariate normality. Mean difference and F-test were used to judge whether the valuers in the two countries have significantly different views on client influence. The researchers' discovered that client influence on valuation practices does exist in both Taiwan and Singapore. This is despite the differences in the market structures, development background and modes of doing business. Furthermore, the study found out that the degree and extent of the problem are different. These differences, as reflected in the differing views and opinions on the causes and factors leading to client pressure, were largely due to the systemic differences in the two countries, particularly, in the way businesses are conducted as well as the medium of communication being used. The purpose of valuation sought for by clients' was also discovered to be a preeminent factor that triggers clients' influence (Iroham, 2007). The study which entailed the survey of 95 Estate Surveying firm in the Lagos metropolis revealed that mortgage valuation was mostly influenced in Nigeria. Other factors such as the type of client, the characteristics of valuers and valuation firms, the purpose of a valuation and the information endowments of clients and valuers also influence clients' influence (Levy and Schuck, 1999). Also clients having expertise and a high level of knowledge of the property market like permitting clients to review draft valuations prior to their formalization as is evident in a country such as New Zealand have also been discovered to influence valuation (Levy and Schuck, 2005). Certain ways by which clients' effect such influences amongst which is offering of higher fees to valuers' or made to continue future engagement. At other times, professional fees are denied - a phenomenon described by Kohli (1989) as the reward and coercive power of clients respectively.

The influence experienced by valuers/appraisers can probably be experienced amongst agents as clients' who are described as principals' in negotiation processes could exhibit tendencies outlined by their counterparts requesting valuation. This is what has prompted this research in a bid to discovering which principalvendor/seller; buyer; lessor/landlord; /lessee/sitting tenant; prospective landlord; or prospective tenantinfluences the negotiating process and by what medium such influences are being exhibited on the Estate Surveyor and Valuer.

\section{Research Method}

The study focused on Lagos metropolis due to its vibrant property market (being the undisputed commercial capital of the country). Besides, the Directory of the Nigerian Institution of Estate Surveyors and Valuers, (NIESV, 2009) reveals that almost 50\% of the head offices of all of Nigeria's Valuation firms are located in that metropolis.

The study investigated Principals' influence on Estate Surveyors and Valuers when it comes to negotiation of 
property both by vendors and also purchasers. The research focused on Estate Surveyors and Valuers as the study populations who are major valuation intermediary in property marketing. Out of the 270 firms in the study area, the use of a demographic formula by Otte (2006) resulted to a total of 159 Estate Surveying firm representing about $59 \%$ of the sample frame was calculated as an appropriate sample size for this study. This represented the total number of questionnaires issued for the study. The research adopted stratified random sampling as its sampling method. Lagos metropolis was stratified into six zones, namely, Lagos Island, Victoria Island, Ikoyi Island, Apapa Island, Surulere and Ikeja business district (as adopted by Ogunba, 1997; Ogunba and Ajayi, 1998; Iroham 2007). Thereafter, there was random selection of subjects in each stratum.

Questions investigated various aspects of client influence as evident in literature particularly in the case of valuations. The views of respondents were measured in a graded manner, using Likert (ordinal) scales. The data were analyzed by means of descriptive statistical techniques, and weighted average frequencies.

\section{The Results}

From the sample size, a total of 122 (representing 76.7\%), of the distributed questionnaires were duly retrieved. Respondents were found to be mostly between the ages of 31-35 years. The average respondent had practical experience spanning about 5 years. The most typical academic qualification of respondents was a B.Sc degree (about $63 \%$ of respondents) while others had little stint in various higher degrees.

Preliminary questions investigated the occurrence of clients' influence on negotiation of real estate. Although Estate Surveyors who are interchangeably described as agents in this research were trying to dodge the existence of such phenomena, ardent investigation into the subject matter reveals that such does exist particularly in a closed market system. According to their responses, that does not preclude its existence also in an open market situation. Investigation was geared towards discovering who amongst the principals- a term interchangeably used in this research for sellers/vendors; buyers; lessors'/ landlords; lessee/sitting tenants; prospective landlords; prospective tenants'- is most apt in influencing negotiation in the property market. Responses were measured on an ordinal scale of five with 5 representing principals' influence on valuations at all times and 1 representing no principal influence. Responses in this regard are contained in Table 1(see appendix below). The weighted average results calculated from Table 1 is $1.97,1.79,2.44,2.77,2.66$, and 3.18 for sellers/vendors; buyers; lessor/landlord; lessee/sitting tenant; prospective landlords; and prospective tenants respectively. On a scale of 5 it is evident that respondents agree that clients'/principals' influence on real estate negotiation do exists particularly during negotiation for letting.

The research also investigated into the different forms the principal/client influence takes. Although out of the 122 respondents whose questionnaires were retrieved only 76 attempted a response to this question as respondents showed some level of reticence; however, much persuasion on confidentiality of report exclusively used for an academic exercise resulted to their eventual response. However, amongst retrieved questionnaires certain respondents still preferred to remain silent in certain options. The investigation made on this question was structured as that of Kohli (1989), whose quest into clients influence was ordered under the following headings:

Reward power (Principals' ability to mediate material and or non-material rewards to agent); coercive power (Principals' ability to mediate material and or non-material Punishment to agent); referent power (An agents regard for and identification with a principal); legitimate power (Formal or Informal norms that call for an agents' compliance with a principal); expert power (An agents' faith in a principals' knowlegdeability); information power (A principals' ability to control flow of information to an agent); and departmental power (The status of a principal in question). Table 2 and Fig 1 which gives the results of the various powers outlined above reveals that reward power and information power are the two most prominent forms of influence exerted by the principal on the Estate Surveyor and Valuer respectively. Upon further investigation the study reveals that prospective tenants who are most apt in using particularly the reward power do it by influencing the Estate Surveyor and Valuer by agreeing to offer the latter their professional fees for two years upfront if the latter can help in convincing prospective landlord in collecting one year rent as against the two years which is usually the norm in Nigeria. Principals' are also observed to keep back certain information particularly those that would be detrimental to their negotiation prowess; this according to the Estate Surveyors and Valuers is usually evident in areas of little or no familiarity of operation.

\section{Recommendation/Concluding Remark}

The reward power used by principals' in influencing Estate Surveyors and Valuers in the negotiation of real estate transaction should be watched and handled with caution so as not to degenerate to the loss of integrity amongst these acclaimed "Noble Colleagues". If the message being put across by prospective tenants is the clamour for yearly rental payment in advance then the Nigerian Institution of Estate Surveyors and Valuers 
(NIESV) and the Estate Surveyors and Valuers Registration Board of Nigeria (ESVARBON) should recommend to local authorities or government the payment of yearly rents and work out modalities where banks would be responsible for monthly deduction of rents from salaries/wages of prospective tenants and onward credit of same to prospective landlords account through the Estate Surveyors and Valuers. The tackling of this at this early stage can also prevent the handling down of cash and other pecuniary baits by principals to Estate Surveyors and Valuers thereby distorting the entire outcome in the property market.

Information has also been used by principals' to influence the Estate Surveyor/Valuer during negotiation. This has once more showcased the power of information which Estate Surveyor/Valuer must strive to attain particularly while working in an unfamiliar location. The need once more for the creation, management of a databank cannot be overemphasized where Estate Surveyors can access instead of making recourse to Principals' for information and at best being left at their mercy in discharging their statutorily function.

From the moral perspective, the issue of influence should not be condoned as it tends to destroy the intermediary role which the agent is to play in real estate negotiation. This should be enforced not minding the principal that engaged the Estate Surveyor and Valuer. Contrary to this, the implication is that the market would tend towards survival of the fittest and not merely resulting from the power of market forces. In the long run information from outcome of any transaction would be handled with levity, which would invariably distort the weight attributed by Estate Surveyors and Valuers to earlier comparable transactions in the Property Market.

Although, this work has succeeded in unraveling the existence of influence in real estate negotiation and how its' been carried out, further works still needs to be done such as probing into its effect in the real property market particularly as it affects valuation and the distortion/lagging in sales/purchases of real estate, if any. However; this study has opened up another study area in real estate research.

\section{References}

Amidu, A., and Aluko, B. T. (2007). Client influence in residential property valuations: An empirical study. Property Management, 25(5), 447-461.

Asami, Y., and Teraki, A. (1991). On sequential negotiation procedures: optimal negotiation orders and land prices. Regional Science and Urban Economics, 20, 537-556.

Ashcroft, S. (2004). Commercial negotiation skills. Industrial and Commercial Training, 36(6), 229-233.

Aycock, S. A. (1999). The Anchoring Heuristic in Real Estate Negotiations: The Impact of Multiple Reference Points on Final Settlement Price. Dissertation,Georgia StateUniversity, Atlanta,GA.

Bazerman, M. H., Neale, M. A., Valley, K. L., Zajac, E. J., and Yong, M. K. (1992). The effect of agents and mediators on negotiation outcomes. Organizational Behavior and Human Decision Processes, 53, 55-73.

Baum, A., Crosby, N., Gallimore, P., Gray, A., \& McAllister, P. (2000). The Influence of Valuers and Valuations on The Workings of The Commercial Property Investment market, Report for the Education Trusts of the Investment Property Forum, Jones Lang Lasalle and the Royal Institution of Chartered Surveyors, London.

Black, R. T., and Diaz, J. III. (1996). The use of information versus asking price in the real property negotiatingm process. Journal of Property Research, 13, 287-297.

Chen, F. Y., and Yu, S. M. (2009). Client influence on valuation: does language matter? A comparative analysis between Taiwan and Singapore. Journal of Property Investment \& Finance, 27(1). 25-41.

Chinloy, P., Cho, M., and Megbolugbe, I. (1997). Appraisals, Transaction Incentives and Smoothing. Journal of real estate finance and economics, 14(1), 89-112.

Cho, M., and Megbolugbe, I. (1996). An empirical analysis of property appraisal and mortgage redlining. Journal of Real Estate Finance and Economics, 13(1), 45-55.

Crosby, N., and Murdoch, S. (2000). The influence of procedure on rent determination in the commercial property market of England and Wales. Journal of Property Investment \& Finance, 18 (4), 420-444.

Crosby, N., MurdocH, J., Hughes, C., and Mubanga, Y. (2004). The Status of Property Valuation. Report to the Economic and Social Research Council UK.

ElShenawy, E. (2010). Does negotiation training improve negotiators' performance? Journal of European Industrial Training, 34(3), 192-210.

Hardin, W.G. III. (1997). Heuristic use, credit constraints and real estate lending. Journal of Property Valuation \& Investment, 15(3), 245-255. 
Hutchison, N. E., Adair, A. S., and Park, K. (2010). The value of rental deposits. Journal of Property Investment \& Finance, 28(4), 250-262.

Institute for Corporate Real Estate. (1992). Skills and Knowledge Related to Success in Corporate Real Estate. NACORE International, West Palm Beach, FL.

Iroham, C.O. (2007). The Influence of Valuers and Valuations in the Workings of Commercial Property Investment in Lagos Metropolis. Unpublished M.sc Thesis, Department of Estate Management, Covenant University, Ota.

Kinnard, W. N., Lenk, M. M., and Worzala, E. M. (1997). Clients' pressure in the commercial appraisal industry: how prevalent is it? Journal of Property Valuation and Investment, 15(3), 233-244.

Kohli, A. (1989). Determinants of influence in organizational buying: A contingency approach. Journal of marketing, 53(3), 50-65.

Kurtzberg, T. C., Dunn-Jensen, L. M., \& Matsibekke, C. L. (2005). Multi-party E-negotiations: Agents, alliances, and negotiation success. International Journal of Conflict Management, 16(3), pp. 245-264.

Levy, D., and Schuck, E. (1999). The influence of clients on valuations. Journal of Property Investment and Finance, 17(4), 380-400.

Levy, D., and Schuck, E. (2005). The influence of clients on valuations: the clients' perspective. Journal of Property Investment and Finance, 23(2), 182-201.

McAllister, P., and Tarbert, H. (1999). Bargaining, utility and rents: Analysing the effect of potential lease termination on rent negotiation outcomes. Journal of Property Investment \& Finance, 17(4), 353-364.

Morris, N. D. (1990). Seven steps to principled negotiation. Real Estate Review, 20(2), 51-55.

Muhlebach, R. (2005). The seven deadly provisions. Journal of Property Management, 70(3), pp. 44-6.

Myerscough, J. M., and Tyler, S. B. (1991). Negotiation education and training, and the surveyors. Property Management, 9(2), 130-144.

Neale, M. A., and Bazerman, M. H. (1992a). Negotiator cognition and rationality: a behavioral decision theory perspective. Organizational Behavior and Human Decision Processes, 51, 157-175.

Neale, M. A., and Bazerman, M. (1992b). Negotiating rationally: The power and impact of the negotiator's frame. The Academy of Management Executive, 6(3), 42-51.

NIESV. (2009). Directory of Estate Surveyors and Valuers, Nigerian Institution of Estate Surveyors and Valuers, Lagos.

Nourse, H. O. (1990). Managerial Real Estate. Englewood Cliffs, NJ: Prentice-Hall.

Ogunba, O. A. (1997). A Study of Valuation and Pricing Methods in the Residential Property Market in Lagos Metropolis, MSc Dissertation, Department of Estate Management, Obafemi Awolowo University, Ile-Ife.

Ogunba, O., and Ajayi, C. A. (1998). An assessment of the accuracy of valuations in the residential property market of Lago. Journal of the Nigerian Institution of Estate Surveyors and Valuers, 21(2), 19-23.

Pfrang, D. C. and Wittig, S. (2008). Negotiating office lease contracts: From a game-theoretical towards a behavioural view. Journal of European Real Estate Research, 1(1), 88-105.

Rondeau, E. P. (1993). The art of the real estate deal. Facilities Design and Management, 12(1), 44-45.

Thompson, L. (1990). Negotiation behavior and outcomes: empirical evidence and theoretical issues. Psychological Bulletin, 108, 515-518.

Valley, K. L., White, S. B., Neale, M. A., and Bazerman, M. H. (1992). Agents as information brokers: The effects of information disclosure on negotiated outcomes. Organizational Behavior and Human Decision Processes, 51, 220-236. 
Table 1. Propensity of Influence by Principals

\begin{tabular}{|c|c|c|c|c|c|}
\hline $\begin{array}{c}\text { Influence on Real } \\
\text { Estate Negotiation }\end{array}$ & Never & Rarely & Sometimes & Most times & Always \\
\hline Sellers/Vendors & 45 & 53 & 11 & 8 & 5 \\
\hline Buyers & 49 & 58 & 9 & 4 & 2 \\
\hline Landlord/lessor & 26 & 42 & 36 & 10 & 8 \\
\hline Sitting tenants/lessee & 19 & 33 & 38 & 21 & 11 \\
\hline Prospective Landlords & 14 & 48 & 34 & 17 & 9 \\
\hline Prospective Tenants & 11 & 21 & 43 & 29 & 18 \\
\hline
\end{tabular}

Source: Authors' field survey

Table 2. Forms of Principals' Influence on Negotiation

\begin{tabular}{|c|c|c|c|c|c|c|}
\hline Forms of Influence & Vendors' & Buyers' & Landlords' & Tenants' & $\begin{array}{c}\text { Prospective } \\
\text { landlords' }\end{array}$ & $\begin{array}{c}\text { Prospective } \\
\text { Tenants' }\end{array}$ \\
\hline Reward power & 13 & 11 & 17 & 15 & 19 & 33 \\
\hline Coercive power & 4 & 1 & 6 & 1 & 1 & - \\
\hline Referent Power & 2 & 1 & 7 & 3 & 1 & - \\
\hline Legitimate Power & 6 & 4 & 3 & 8 & 1 & 4 \\
\hline Expert Power & 6 & 5 & 11 & 8 & - & - \\
\hline Information Power & 12 & 16 & 12 & 18 & 15 & 17 \\
\hline Departmental Power & 11 & 9 & 11 & 12 & 11 & 8 \\
\hline
\end{tabular}

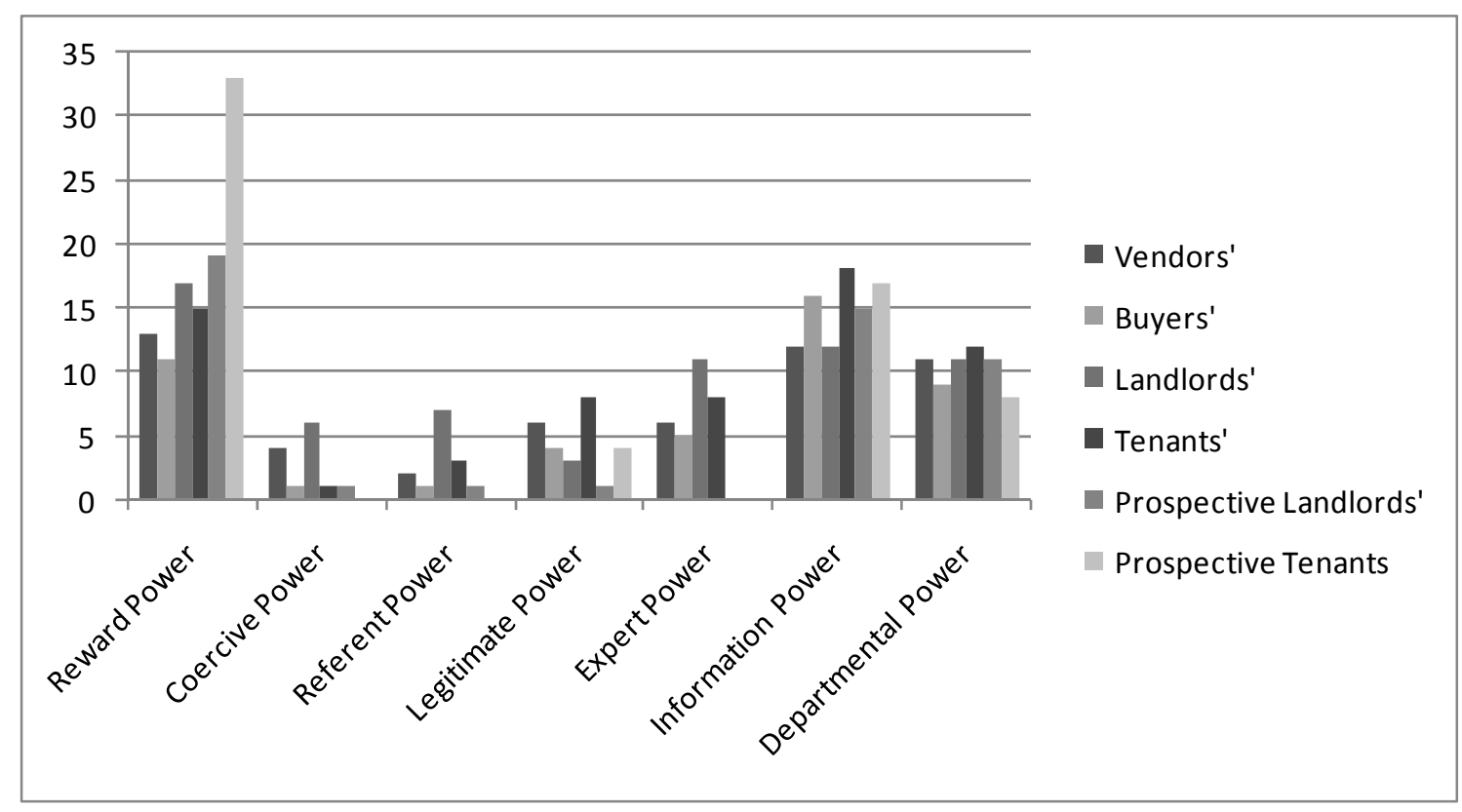

Figure 1. Component Bar Chart of Principals' Influence on Negotiation

Source: Authors' field survey 